\title{
Shadows Under a Rising Sun: Utopia and Its Dark Side in Kirino Natsuo's Poritikon
}

\author{
Adam Gregus
}

\begin{abstract}
Kirino Natsuo, arguably one of the most popular contemporary Japanese authors in Western markets (a number of her novels having been translated into English, German, French, Italian, Dutch or Spanish, among other languages) who is often being recognised as a mystery writer, only enjoys limited acknowledgment for the thematic breadth and genre diversity of her work. Such description is not only inaccurate (Kirino published her last true mystery novel in 2002), but also manifests itself in the limited and underdeveloped treatment of her work in Western academic writing. This paper deals with Kirino Natsuo's 2011 novel Poritikon (Politikon) and its analysis within the greater context of Kirino's work. A focus is put upon introducing the novel as utopian fiction with the aim to illustrate ways in which Kirino Natsuo utilises utopian genre patterns as well as how her utopia works to provide a commentary on contemporary Japan. The utopian theme present in Poritikon makes the novel a rather untypical entry in Kirino's oeuvre (although not a unique one, since her novels Tōkyō-jima [Tokyo Island, $2008^{1}$ ] and Yasashii otona [Gentle Adults, 2010] also work with elements of utopian/dystopian fiction) as well as within the Japanese literary scene in general, and provides an interesting argument for Kirino Natsuo as more than 'just' a mystery writer.
\end{abstract}

Keywords: Utopia, Dystopia, Kirino Natsuo, Japanese Literature, Atarashiki mura

Drae Gregus, Adam. "Shadows Under a Rising Sun: Utopia and Its Dark Side in Kirino Natsuo's Poritikon." In Vienna Journal of East Asian Studies, Volume 8, eds. Rudiger Frank, Ina Hein, Lukas Pokorny, and Agnes Schick-Chen. Vienna: Praesens Verlag, 2016, pp. 1-31. https://doi.org/10.2478/vjeas-2016-0001

1 Dates given refer to the first publication in book form. 


\section{Introduction $^{2}$}

Kirino Natsuo 桐野夏生 (b. 1951) has become one of the most popular Japanese authors over the last decade. Since her 'official' debut in $1993^{3}$ with Kao $n i$ furikakaru ame 顔に降りかかる雨 (Rain falling on her face), she has enjoyed continued significance in Japan, having been awarded numerous literary prizes over the years. Kirino's commercial breakthrough, the highly acclaimed novel Auto アウト (OUT, 1997), has also become the first work from her rather expansive oeuvre to be translated into English (2003), earning the author a relatively broad international exposure. OUT has proven to be successful abroad on both commercial and critical terms, being the first Japanese novel to win the prestigious Edgar Allan Poe prize in 2004.

A substantial part of Kirino's oeuvre defies simple genre classification, and yet she is best known as a mystery writer, both in and outside of academic circles. She has also been described as a writer of joryū bungaku 女流文学 ('women's literature'), as a shakai-ha 社会派 writer (literature of social criticism), even as a writer of 'new proletarian literature'. In this respect, her 2011 novel Poritikon ポリティコン (Politikon) provides an interesting, if little discussed, example of Kirino's treatment of genre. The novel utilises genre patterns of utopian and dystopian literature-interestingly not the most popular genre in Japanese literature - and, in doing so, displays her unconventional employment of genre as such. In addition, the novel also features numerous recurring motives of her work, such as blending fact and fiction, or focusing explicitly on underprivileged spheres of Japanese society.

The novel, as of 2016 available only in Japanese, is both Kirino's longest work to date (spanning over 800 pages in its hardcover edition, published in two volumes) and a striking departure in style from her previous output. It deals with a fictional utopian community called Iwan-mura 唯腕村 located in the northern Tōhoku region. The reader gets acquainted with this community both through the lens of the community's native Takanami Toichi 高浪東一, as well as an outsider, i.e., Nakajima Maya 中島真矢. A major reason behind taking up Poritikon as one example of Kirino's fictional works in this paper is its underexposure in academic writing on Kirino Natsuo and the novel's potential to illustrate the thematic breadth of Kirino's oeuvre, a point often neglected in examinations of her work.

2 This paper is a revised and shortened version of the author's M.A. thesis (Gregus 2014).

3 Kirino was already a published author by this point. The 1993 novel is, however, often treated as her first (including on Kirino's official website). 


\section{'I live to love my friends, live to love the soil, live for the people': Kirino Natsuo's Poritikon}

Tackling utopian motives is a rather unusual move for Japanese authors, with literary utopias usually failing to make any significant impact even when they are written by well-established authors (such as, for example, Mishima Yukio 三島 由紀夫 or Ōe Kenzaburō 大江健三郎). ${ }^{4}$ Some scholars even state that it was no longer viable to write about idealised, flawless societies: The effectiveness of utopian literature in contemporary socio-political contexts is disputable, with sociologist Krishan Kumar having pronounced it dead already in 1987 (Kumar 1987: 380), and English scholar Christopher Ferns questioning the ability of newer utopian writing to challenge the dominant ideology (Ferns 1999: 234). All these opinions, however, are indeed reasons for taking a closer look at Poritikon.

With Poritikon, Kirino takes up the utopian theme in the most explicit manner among her works: The utopian society portrayed in Poritikon, an agricultural commune called Iwan-mura (itself a reference to Tolstoy's short story Ivan the Fool), ${ }^{5}$ is of central importance to the novel's plot and its protagonists, Takanami Toichi and Nakajima Maya. The protagonists' existence is profoundly influenced by their life in the community, albeit in very different ways and contexts. It is also important to note that Kirino Natsuo creates 'her own' utopia only in part: Although Iwan-mura is a fictional place, she explicitly alludes to the existing commune of Atarashiki mura 新しき村, even endowing Iwan-mura with a similar history. This allows her to create a link between past and present Japan, as well as between fact and fiction, a staple of her writing. While literary utopias have served as inspirations for the founding of utopian communities in the past, Kirino reverses this dynamic in Poritikon. This article aims to examine both Kirino's construction and treatment of utopia as social commentary.

The novel's title might be a good point to start these examinations. The word politikon comes from Aristotle's concept of a zoon politikon, that is a 'political animal' or a social being, given that Aristotle does not separate politics and society (Tunçel 2012: 245). According to the philosopher Christoph Rapp, the political nature of human beings means that they can only develop themselves within the framework of a society governed by law-the state-due to their need for

4 Mishima's Utsukushii hoshi 美しい星 (Beautiful Star, 1962) was a commercial failure, although Mishima himself reportedly considered it his most artistically successful work, while the commercial performance of Ōe’s Chiryōtō 治療塔 (Tower of Treatment, 1990) suggests that the Japanese literary market still has not warmed up to utopias nearly three decades later.

5 The story deals with the simple peasant Ivan and his two brothers, who become a soldier and a merchant respectively. They mock Ivan for sticking to farming, but it is he who ultimately comes to rule the country, Tolstoy's moral being that farming is the most honourable work of all. This, as pointed out by Kumar (1987: 26-27), is a pattern to be found in much of utopian literature. 
cooperation, pursuit of self-sufficiency (autarky) and ability to communicate through speech (Rapp 2001: 55). On the other hand, writer Satō Masaru 佐藤優 focuses on the basis of the word polis (city-state), an opposite of oikos (economy, household), with nomos (law, order) being the fundamental principle of polis. At the same time, the basis of an oikos is bia-violence, through which, in Greek thought, men were supposed to control the household and economy (Satō and Kirino 2009/2012 ${ }^{6}: 202$ ). In the novel's context, the concept of zoon politikon is used in an ironic fashion on multiple levels: Firstly, a utopian commune represents a rejection of its members' society (in this case, Japan) and as such could be seen as an assembly of people who could not find human satisfaction within the framework of a 'state'. Secondly, Kirino chooses to depict her two protagonists as having completely different, even contrasting, backgrounds and personal histories, yet living as misfits both within and outside the utopian community of Iwan-mura. Satō's focus on the words polis and oikos is intriguing as well, considering that the economic hardships of Iwan-mura play a central role within the novel's plot; the metaphorical 'city-state' of Iwan-mura is constituted by its few households, and both are mutually dependent. What is more, 'law and order' and 'violence' become entwined with foul power play in the village and an involvement of a group of yakuza (gangsters) in its economic matters. The title's significance and the novel's socially critical and utopian elements shall be discussed in more detail below.

In a 2008 interview with Satō (when the novel only began its serialisation), Kirino admitted that she had attempted to write Poritikon in a somewhat different tone from her other works: Calling it an 'experiment', she claimed that her aim was to explore the 1960s phenomenon of communes and to pursue the question of what happens after a charismatic leader draws people to live together. Her intention was to move away from 'writing about small-minded people', which she had done until then, and to attempt to grasp the concept of charisma (Satō and Kirino 2009/2012: 210). The novel apparently also went through a number of transformations from the initial concept Kirino mentions in an interview with Minagawa Hiroko 皆川博子. She speaks of her fascination with taiga shōsetsu 大河小説 (which could be loosely translated as 'saga' or roman-fleuve), which depict their characters' undergoing change within a long span of time; she also speaks of her idea to write a novel about a group of young people who create their own country, and how she might dismiss her initial plan to write it as an 'ensemble novel' (gunzō shōsetsu 群像小説) ${ }^{7}$ in favor of the taiga shōsetsu form (Minagawa and Kirino 2009/2012: 56). Kirino also elaborates on this first concept in an interview with Sasaki Atsushi 佐々木敦, saying that, at first, she wanted to write a story about political refugees and people

6 The two dates refer to the first publication date (in book form) and the publication date of the edition used respectively. This applies to all instances of two given publication dates throughout this text.

7 See Glossary. 
wanting a different nationality, which motivates them to create their own state. Then she would think about how they would manage this state, and wanted to incorporate the aspect that a nationality was something one could purchase by credit card. She developed the small community of Iwan-mura from her reflection on the idea of what would become of people once they overcome the boundaries of a nation (Sasaki and Kirino 2011). In a 2008 interview with fellow writer Bandō Masako 板 東眞砂子, Kirino speaks about her original intention to set the novel in Tōyō-chō, in the Kōchi Prefecture (located on the southern island of Shikoku - a stark contrast to the northern setting of Iwan-mura in the Yamagata Prefecture). At this stage, the novel was supposed to be premised on the fact that the Japanese puppet state of Manchukuo still existed and its people would gather in Kōchi, participating in the creation of a new country (Bandō and Kirino 2009/2012: 224-225).

Another difference between Poritikon and Kirino's earlier novels is the author's intention to move away from what she calls 'city novels' (toshi shōsetsu 都市小説). She argues that even her previous novel Tōkyō-jima 東京島—a story of survivors on an abandoned island - could be described as such. Focusing on the countryside and its specific problems - in this case, an aging and declining population-would allow Kirino to take up problems specific to (contemporary) Japan; on the other hand, the 'low life' in Tōkyō might actually not be that far away from that in New York (Bandō and Kirino 2009/2012: 226-227). It should thus be examined in what ways Kirino treads new paths in Poritikon and which of her literary patterns recur.

\section{Kirino Natsuo's Construction of Utopia}

As mentioned earlier, Kirino Natsuo's employment of utopian/dystopian narrative patterns is a rather unusual move within the field of Japanese literature. In that sense, her construction of a utopian community, the contexts in which the concept of utopia is being discussed within the novel, as well as the position of Poritikon within the frameworks of 'Western' and 'Japanese' utopias constitute interesting points when looking at Kirino's employment of utopian tropes.

It can be said that the novel actually opens twice: In the prologue written from Maya's perspective, and in the first proper chapter, written from Toichi's perspective. Interestingly, as discussed above, the two openings feature classic utopian (Maya) and dystopian (Toichi) tropes in establishing a narrative. Maya is forced to flee to Iwan-mura with her mother's ex-boyfriend Kunita, the North Korean refugee Suon, and her son Akira as a sham family after her mother is arrested in North Korea for transporting fugitives. Kunita recounts that he tried to enter Iwan-mura before, when he was homeless, but was refused by Toichi due to his advanced age; his reasoning for coming to the village again is that a family cannot be sent away so easily. He also assumes a fake identity under the name 
Kitada Minoru 北田実 (Kirino 2011a: 19). The 'family' then embarks on a relatively lengthy journey (Kirino 2011a: 21-24), which serves to establish Iwanmura as a remote place and calls to mind the classic narrative device of a 'journey to utopia' (Frye 1965: 324). On the other hand, Toichi's first chapter opens in medias res, much in the same way as Moylan (2000: xiii) describes a typical establishing scene of a dystopian narrative: The narrative's opening focuses on a subject that is part of the (dystopian) society, through which the setting acquires an everyday quality. In this fashion, Poritikon's first scene describes Toichi walking on a snowy landscape, until he finally arrives at Iwan-mura's entrance and proceeds to remove ice and snow from its symbol, a three-meter long totem pole (Kirino 2011a: 3235 - which in itself might serve to establish Iwan-mura as a place of antiquated ideals, detached from the life of most Japanese. Kirino's double establishment of the narrative suggests the contemporary closeness, if not outright inseparability of the utopian and dystopian.

Iwan-mura is described as being founded in 1917 in Mabuchichō, in the prefecture of Yamagata, under the influence of Tolstoy's Christian humanism and named after his short story Ivan the Fool (1917). There are three general rules to follow ever since Iwan-mura's foundation: Unconditional love for others, prohibition of private property, and self-sufficiency; Iwan-mura is the only surviving utopian community from that time, alongside the real Atarashiki mura (which is also mentioned in the novel). The founding members are Raga Makoto 羅我誠, a fictional writer belonging to the Shirakaba 白樺 group, and Takanami Sohō, a sculptor (Kirino 2011a: 33-34). Of these two, it was only Takanami who would remain in Iwan-mura and devote himself to its growth, while Raga provided financial support for the village with his writing, living in Tōkyō (Kirino 2011a: 36). The village's symbol - the totem pole - is a joint work of the two, being sculpted by Takanami and containing the aforementioned "Iwan-mura manifesto" written in Raga's handwriting: 'I live to love my friends, live to love the soil, live for the people' (Kirino 2011a: 35).

When the plot begins in 1997, the village is home to twenty-two people (Kirino 2011a: 44), most of them over the age of fifty. Artistry is central to Iwan-mura's existence: In spite of its economic hardship, artistic endeavour in the village 'flourishes' (Kirino 2011a: 49). This is also manifested through the village's museum that was established by Raga, storing his writings and manuscripts, but also paintings and sculptures of Takanami Sohō and works of art by the village's elderly artists, such as pottery, oil paintings, or calligraphy (ibid.). The museum also houses a replica of Rodin's "Le Bourgeois de Calais", and also serves as a display of the village's history (Kirino 2011b: 8). Iwan-mura also has its own theatre troupe called Aiban あいばん (likely a pun on the name Ivan), supervised by the (at the novel's beginning) village's chairman, Toichi's father Soichi. The theatre troupe consists of villagers, but also has to accept outsiders as actors due to the villagers' age; it is also 
the reason for a young theatre enthusiast to apply for a community membership (Kirino 2011a: 50-51).

Apart from the members living in the village, there are also non-residential members, supporters who are sympathetic to the village's cause. While there have apparently been many of these during Raga's lifetime, their number has significantly reduced by the beginning of Poritikon's plot (Kirino 2011a: 45) and their role as financial supporters does not have any real value to the village (Kirino 2011a: 186). Iwan-mura also holds the so-called 'mutual criticism meetings' (sōgō hihan-kai 総 合批判会) once a month, where village members are allowed to express frank and critical opinions on others - however, as far as Toichi himself can remember, the members would avoid fights and the meetings feel as a mere obligation (Kirino 2011a: 47).

Kirino's fictional Iwan-mura is closely modelled after Mushanokōji Saneatsu's 武者小路実篤 Atarashiki mura, as far as the former's backstory mirrors that of the latter. ${ }^{8}$ Kirino even creates parallels as minute as mentioning a statue by Rodin within the village, which attests to her detailed research. However, Kirino completely avoids the utopian trope of ahistoricity and 'absence of genesis' (Ferns 1999: 98) by modeling her utopian community after an existing one, as well as discussing Iwan-mura's genesis extensively within the novel itself. At the same time, constructing a fictional commune and fictional founder figures serves to make the link to Mushanokōji and Atarashiki mura appear ambiguous, since both communes are referred to within the novel as existing concurrently.

\section{Poritikon's Protagonists}

Structurally, Poritikon is broken down into two parts, with the first one focusing on the Iwan-mura native Takanami Toichi and the second one on Nakajima Maya, who comes to seek shelter in the commune following her mother's arrest in North Korea. The two parts have not been serialised successively ${ }^{9}$ and do not take place at the same time (as would usually be the case with Kirino's multiple perspective narratives). Kirino herself admits that she abandoned her usual narrative method in Poritikon, choosing to focus on the story of a single person in each of the two respective parts of the novel (Sasaki and Kirino 2011). It is also important to note that the first part is longer (Toichi's part is six chapters long with a greater page count) than the second (Maya's story spans four chapters, as well as the prologue,

8 For a brief introduction to Atarashiki mura, see Gregus 2014: 48-52.

9 The first part was serialised in the magazine Shūkan bunshun 週間文春 from the August 16-23, 2007 issue to the November 27, 2008 issue. The second part was serialised (under the title Apokaripushisu アポカリプ シス [Apokalypsis]) in Bessatsu Bungeishunjū 別冊文芸春秋 from the January 2009 issue to the November 2010 issue. 
which oddly was only published later, during the novel's magazine serialisation). It could thus be said that the novel focuses more on its male protagonist. Although this might seem unusual for a Kirino novel, considering the attention her female protagonists usually get in the discourse on her work, Kirino has been increasingly focusing on writing from the perspective of male characters in Metabora メタボラ (2007), Tōkyō-jima (2008) and Yasashii otona 優しいおとな (2010), ${ }^{10}$ all published shortly prior to or during Poritikon's conception and serialisation.

\section{'Selfish Vitality': Takanami Toichi}

Takanami Toichi, the male protagonist of Poritikon's first part, is 27 years old at the beginning of the novel, and the only young person remaining in Iwan-mura. Obviously, Kirino paints the picture of an aging society in a rather extreme fashion; the only other remaining Yamagata native appearing in the novel is Toichi's friend Yoshiyuki 良幸, who keeps to be a minor character throughout. The secondyoungest resident ${ }^{11}$ of Iwan-mura at the plot's beginning is Kumada Alice 熊田 アリス, a 48-year old former hippie who moved to Iwan-mura in the 1960s. Within the first pages of the first chapter, Toichi is described as a farmer leading an uneventful life (Kirino 2011a: 37). Toichi's bond to Iwan-mura is largely a familial one, as he is the son of the commune's chairman (rijichō 理事長) Takanami Soichi 高浪素一, and a direct descendant of Takanami Sohō 高浪素峰, a (fictional) sculptor and one of the village's founders. This bond is further underlined by the opening scene of the first chapter-readers encounter Toichi as he removes ice and snow from the totem pole jointly created by Takanami and Raga. Toichi also has a recurring nightmare in which Raga appears and admonishes him that Iwan-mura, rather than Japan, is Toichi's fatherland and that he is obliged to watch over it, calling him 'Iwan-mura's purebred' (Kirino 2011a: 36-37). Later, Toichi discovers that his biological mother is in fact Raga's granddaughter Kazuko 和子 (instead of his supposed mother Yaiko ヤイ子, who is unrelated to the village's founders), which makes him a descendant of both founders. Kazuko lives in Tōkyō-moving there eventually becomes Toichi's sole experience of living outside of a utopian community until the novel's last chapter.

Despite Toichi's hunger for power, he rather ends up fulfilling roles imposed on him by this miniature society. Yamaji Hiroshi 山路広志, an independent farmer and a leader figure that emerges during the course of the novel, suggests that Toichi become a publicity figure or a 'face' of the village, which could have a positive

10 The dates refer to the publication of the tankōbon 単行本 editions- the first publications in book form.

11 The second youngest person staying in the village at the novel's beginning is Kaneshiro, who is around Toichi's age. However, he is only admitted as a resident member together with Kunita/Kitada's family (Kirino 2011a: 163). 
effect on the village's economic situation (Kirino 2011b: 82-83). A similar suggestion is made by a young researcher and farming enthusiast called Tachibana Yūsuke 立花夫妻, who sees Toichi as Iwan-mura's 'PR manager' (Kirino 2011b: 193), and to whom Toichi poses the question whether he should become the village's next Raga Makoto and gather money in 'risky ventures' (ibid.); Toichi would become an entity bound together with the village in the public's consciousness, but never actually running it. Toichi also realises that he would still have no place to fit within this new conception (Kirino 2011b: 194). On the other hand, it is Toichi himself who starts to use the name 'Raga Toichi' 羅我東一 in exchanges with business partners and mass media by his own volition prior to both of these proposals, and thus in a way acquires a new identity, more closely and obviously associated with the well-known founder Raga Makoto. Assuming the name Raga stands for an appropriation of power, of a 'name', yet even this proves futile in the end, as evidenced by the villagers' ousting of Toichi in the novel's final part. In addition, Toichi's reputation is problematic outside the village. On the one hand, he is hailed as a pioneer of organic farming, building a village which puts ecology in practice and 'preserves the soul of agriculture' (Kirino 2011b: 128). On the other hand, he is dismissed as an 'amateur who knows nothing of farming' (ibid.). Thus, the first part of Poritikon ends on a rather undecided note, and it is unclear whether Iwan-mura will eventually thrive and what exactly Toichi's position is going to be.

\section{Afterimage: Toichi, Ten Years Later}

In the second part of Poritikon, Toichi is portrayed from Maya's perspectivetherefore, readers are not privy to his own thoughts on his life anymore (although Kirino somewhat distances both protagonists from the readers by narrating in third person). On the other hand, Maya reflects on her past in Iwan-mura numerous times, thereby providing a certain counterpoint to Toichi's perspective on their relationship and the circumstances of the village life. Maya's observation as an outsider is made even more subjective and one-sided in that Iwan-mura has obviously undergone a radical change, as has Toichi himself. Maya contemplates how Toichi has visibly gained weight, wealth, and social status, and additionally learned how to conceal his true feelings (Kirino 2011b: 308). She also sees the 'new' Toichi as a man who has earned much - a family, presidency over Iwan-mura and social status - and does not want to lose any of it. At the same time, this makes her realise how much of a disturbance she could be to Toichi, putting her in a position of power in their relationship (Kirino 2011b: 315). Maya also learns about Toichi's womanising, now made possible by the arrival of young workforce in the village, and the fact that his secretary Nao is in fact also his mistress; she imagines this as a possible 'beginning 
of his downfall' (Kirino 2011b: 317). This downfall-Toichi being renounced as Iwan-mura's chairman - actually comprises the climax of the novel's plot, and it is a direct effect of Maya's confession to Alice that, in the past, Toichi had sold her to a yakuza boss (Kirino 2011b: 304). In a move reminiscent of other Kirino protagonists—such as Yawaraka na hoho's 柔らかな㚘 (Soft Cheeks, 1999) Kasumi-Toichi finally leaves the village for good with Maya, abandoning his family and children.

It is somewhat problematic to perceive Toichi, Poritikon's primary protagonist, as a character calling for readers' identification. Although his position of an outsider in society is in line with many of Kirino's other characters throughout her work, Toichi is portrayed as an extremely singular entity. He is used to an unconventional lifestyle; this holds true not only for the time he spends in a big city as represented by Tōkyō (with his failure to adapt that forces him to return to Iwan-mura) but also in the years spent in the countryside, since he had been living in a commune all his life and is thus used to different patterns of day-to-day life and human relationships. It can therefore be said that the issues he faces throughout the course of the novel stem from his inability to adapt to an environment the majority of Japanese live in, contrasting somewhat with other Kirino's male characters, who are often nonconformist but populate more 'familiar' surroundings or lead more 'familiar' lifestyles.

\section{'Unbelievable Loneliness': Nakajima Maya}

Poritikon's other protagonist, Nakajima Maya, is a character in many ways constructed as a counterpoint to Toichi, especially in the novel's first part portrayed through his perspective. It is in the second part that Maya is granted her own voice (along with her name being written in kanji, instead of katakana as in the first part), and it is here that Kirino further elaborates on her 'otherness', but also on a bond with Toichi, which appears to be so much as nonexistent in the first part. As an outsider and an eternal misfit (as will be described below), Maya provides a different perspective on utopia: Possibly also due to her being a female protagonist, she is much more in line with the 'new' and more critical utopian writing (offering more progressive perspectives on gender, among other aspects, and distancing itself from portraying utopias as 'final solutions') than the 'typical' male protagonist of classical utopias.

As opposed to the 'Iwan-mura purebred' (and by extension, a descendant of representatives of Japanese culture) Toichi, Maya is portrayed throughout Poritikon's second part as a person with no home, uprooted from some unknown place of origin. She reflects on her father being a one-eighth Russian Korean, making her 'one-sixteenth Russian, seven-sixteenth Korean and eight-sixteenth 
Japanese' (Kirino 2011b: 296), with the possibility that her mother was in fact Korean as well, making her feel 'as if it was her fate to be away from her homeland' (ibid.). Trying to grasp Maya's ethnicity in such minute numbers instead of just introducing Maya as a mixed Russian, Korean and Japanese appears to be Kirino's way of underlining the importance of ethnic otherness in Japanese society; this is particularly stressed by the fact that the negligible ratio of 'one-sixteenth Russian' is explicitly mentioned. Maya's Korean heritage cannot be considered as unrelated to her portrayal as an eternal outsider - be it in Iwan-mura as a freeloader without having anything to contribute (Kirino 2011b: 25) or, quite literally, as homeless in Sendai, sleeping on benches and washing her face on public toilets (Kirino 2011b: 217). Although discrimination based on her ethnicity is not an issue in the novel, her (not completely clear) descent obviously contributes to Maya's feeling of homelessness. In a polar opposition to Toichi's attachment to Iwan-mura, Maya lacks a sense of belonging to any place, causing her to tell him that 'we should quickly throw away (the place) where we were born' (Kirino 2011a: 200).

Maya finds herself unable to adapt to Iwan-mura since, by her own admission, she finds the prospect of people living in a community with shared property 'unbelievable' and 'strange' (Kirino 2011a: 202-203); on another occasion, she poses a rhetorical question whether all of the villagers are not just unhappy castaways (Kirino 2011b: 73), essentially putting the reason of utopias' existence in question. Yet she and her 'brother' Akira アキラ enjoy the villagers' affection, in spite of everybody being aware that their family is a sham - her 'father' Kitada/ Kunita 北田/クニタ and his 'wife' Suon スオン become indispensable workforce for the village, which allows Maya to freeload in the village and get her high school fees paid without any criticism raised (Kirino 2011b: 25). Maya's recollection of Iwanmura in Poritikon's second part is first described in negative terms, with Maya concluding she never wants to return (Kirino 2011b: 203); on other occasions, however, she is overwhelmed by feelings of nostalgia, missing the years of living in 'that old, poor village' (Kirino 2011b: 264), while realising that this very same village is gone for good after she witnesses its transformation into a 'Disneyland' on television (ibid.). It is because of this change, as well as Toichi's newfound status as a kind of celebrity, that Maya realises she became a 'harmful presence to himself and the village' (Kirino 2011b: 311) that denies her the opportunity to find something like a 'home' in Iwan-mura for good. However, it appears that home is not what Maya is searching for throughout the novel. In a stark contrast to Toichi's troubled relationship with Tōkyō, she finds living there desirable precisely because people do not care about each other in a big city, yet concluding that big city life is not lonely because people are everywhere around (Kirino 2011b: 225).

Kirino makes Maya's and Toichi's bond seem rather like one of two outcasts driven together by fate than one of lovers or even one of mutual understanding. It is also hard to read Toichi's and Maya's final escape as a happy ending, considering 
their mutual history and the fact that Toichi had an irreversible - and negativeimpact on Maya's life. Kirino may therefore be making a rather somber statement on the situation of women in Japan: With Maya, she might be illustrating the strength of the hold patriarchy still has on them, no matter how defiant or independent they might (aspire to) be. However, by claiming that Toichi and Maya 'finally become Adam and Eve' (Sasaki and Kirino 2011), she offers another perspective on the ending: Here, Kirino might be referring to the ending of John Milton's Paradise Lost (1667), an epic poem dealing with the expulsion of Adam and Eve from the Garden of Eden. Tony Blackshaw interprets their life after Paradise as life after community, with the realisation that if they are prepared to support one another and find Paradise between themselves, they might become happier than they once were in Eden (Blackshaw 2010: 28-29).

\section{Utopia's Dark Side: Iwan-mura's Problems}

In Poritikon, the existence of Iwan-mura is increasingly plagued by problems of economic nature, which become one of the novel's most explicit manifestations of the impossibility to think of a utopian society completely removed from the society at large (in this case, Japan). At the beginning of the novel, Toichi ruminates upon the fact that the village cannot accept any new members due to its low production output, as it would economically collapse (Kirino 2011a: 44). The flagship product of Iwan-mura are eggs, supplemented by shiitake 椎茸 mushrooms, umeboshi 梅干 (dried and salted plums), homemade miso 味噌 and other produce, while all members agree to donate their annual premiums to the village. Another source of income for the village is the revenue of the Aiban theatre troupe, which at some point would tour all over Japan and sell out performances every night - however, the troupe presently performs at the village assembly hall, with tourists or fans visiting, or at senior homes. Due to economic circumstances, the village has to rely on monetary income instead of doing barter trade as in the past, thus being forced to give up on the ideal of self-sufficiency (Kirino 2011a: 57-58). Iwan-mura's ban on private property applies to housing and land, as well as private savings, with the village's revenue being split evenly among its members (Kirino 2011a: 75); meals are served in exchange for meal tickets (Kirino 2011a: 66). Iwan-mura's forced relaxation of its rules is also well illustrated by the character of Toshima Ruriko 豊 島ルリ子, who has been admitted to the village in spite of being over the admission age limit of 45 years, because she had donated most of her retirement money, allowing Iwan-mura to buy a truck and make concrete flooring in the poultry house (Kirino 2011a: 45-46).

Since Iwan-mura is not eligible for official subsidies and cannot apply for a loan as expressly as needed (Kirino 2011a: 185-186), Toichi (as the new chairman) tries 
to raise money for the village in a number of ways. He pitches Iwan-mura's eggs to a luxury grocery store chain (Kirino 2011a: 406) and together with Kitada comes up with plans to promote tourism in Iwan-mura (Kirino 2011a: 370). However, already early on, he considers less honest ways to make money, such as producing eggs of lesser quality and selling them as high-quality produce (Kirino 2011a: 183). Most importantly, he gets mixed up with members of the yakuza, selling discarded chickens (old ones which do not lay eggs anymore) as freerange ones (Kirino 2011a: 432). It is this business with the yakuza which gets Toichi-and by extension, all inhabitants of Iwan-mura-in a debt, which is only repaid by selling Maya, who is subsequently forced to work for the crime ring.

By constructing Iwan-mura as quite literally a poor place, Kirino reverts the utopian trope of the fictional utopia as a place of excess, or at least a place of order and sufficiency. This reversion, however, could not be avoided if Kirino wanted to portray the problems of the Japanese countryside through Poritikon and mediate an unsentimental, plausible picture of rural Japan's reality. Still, it is telling that Iwanmura is not removed from this harsh reality and, instead, Kirino chooses her 'utopia' to struggle with the same problems as its 'un-utopian' surroundings, suggesting that any utopian struggle and idealism would not materialise without considering the outside world that forms it.

\section{Homogeneity vs. Heterogeneity in Poritikon}

Given Kirino's prior portrayal of middle-aged to elderly women as strong and selfsufficient - e.g. in OUT and Tamamoe! 魂萌え! (Awaken Your Spirit!, 2005)—her description of the village's 'housewives' (poultry raising expert Hatakeyama Mikiko 畠山幹子, Komatsu Fusae 小松房江 running the village dining hall, and Toichi's mother Yaiko), all of them in their sixties or seventies, as 'holding the village up' (Kirino 2011a: 71) does not come as a surprise. Kirino, however, is quick to add that the village would be lost without a younger generation to take it over, since the old villagers are slowly but surely becoming unable to work (ibid.). The people of Iwanmura realise that aging and depopulation are not problems limited to the village, but affect all of the Japanese countryside. According to Alice - the second youngest resident of the village at the novel's beginning - this issue is exaggerated in Iwanmura because the village children get to feel the difference of their lifestyles while attending school with children from the 'outside', causing them to leave later on (Kirino 2011a: 76-77). The difference in portraying the elderly as less capable of taking charge of their own lives (as in, for instance, Tamamoe!) might be rooted in Kirino's intention to write about acute problems in Japanese society. As mentioned above, this was a prominent motivation for her to situate the novel in Japan's countryside. While the middle-aged to elderly living in the cities mostly have their 
families - or at least an urban infrastructure - to rely upon, the Japanese countryside is quite literally dying out. After the population of Iwan-mura increases somewhat over the course of the plot, Toichi-as the newly appointed chairman-decides to transfer the village's bedridden, sickly, or mentally deteriorating elderly to appropriate institutions in cities, effectively providing them with care, yet still earning the grudge of some of the older residents (Kirino 2011b: 18).

On the other hand, the village's residents are also portrayed as having difficulties with cultural or ethnic otherness, which becomes a key point in the development of the plot. The original representative of this conflict with otherness is Alice, who came into the village in the 1960 s as a hippie, when Iwan-mura was enjoying a period of fame as Japan's pioneering commune, along with Raga Makoto's granddaughter Kazuko (Toichi's biological mother) and others. She would be the only one from the group to remain in the commune, bearing two children, then eloping with a lover and leaving them to be raised by Yaiko, only to eventually return to Iwan-mura for good. The depopulation is actually given as a possible reason for Alice to remain in the village - the relationships are unchanging, calling to mind the 'stasis' often portrayed in utopian writing. This can possibly provide comfort to Alice (and Toshima Ruriko), since devoting themselves to the community has become their reason for living (Kirino 2011a: 52). Still, Toichi recounts that according to what he has heard of the village's history, first-generation resident Hatakeyama Katsuyuki 畠山克之 and his son Shigeyuki 畠山繁之 would make an obstinate effort in trying to drive the hippies out of the village, with Shigeyuki openly disliking Alice even in the present (Kirino 2011a: 56). This negative attitude does not only apply to Alice but to her sons as well, with Shōma admitting to Toichi that they were 'both treated as burden from the start' (Kirino 2011a: 267) due to their 'outsider' origin, ingraining a mistrust for the village's ideals within the two boys (ibid.).

This conflict with otherness becomes even more vivid when the village experiences an increase of foreigners, starting with Kunita/Kitada's sham familyputting the village's ostensible homogeneity at stake. At one point, Suon complains to Toichi about how she has trouble getting rice from villagers (even though she takes over the responsibility of cooking for the village) who would rather avoid her than voice their opinions clearly, concluding that 'the Japanese don't like declining' (Kirino 2011a: 239). Suon makes two acquaintances of hers come to Iwan-mura during Toichi's absence, which motivates him to come back from Tōkyō and become the village's chairman before Kunita/Kitada could manage to win over the trust of the residents (Kirino 2011a: 302). One of these is the Vietnamese Hoa ホア (Toichi's future wife), who had been previously married to a middle-aged Japanese farmer. The other one, Mei メイ, is a Chinese disappointed by the Japanese family she had wed into, running away and surviving by working nighttime entertainment jobs (mizu shōbai 水商売). Suon even asks whether she could invite more women 
like her, which Toichi agrees to, with a tacit expectation of sexual favors in return (Kirino 2011a: 355-356). The change this brings to Iwan-mura becomes obvious to Toichi during his father's funeral, when he sees almost exclusively foreign food prepared for the reception (Kirino 2011a: 325); he also experiences the mistrust the foreign women face from the older villagers, when Yaiko complains about how they 'can't even burn incense properly' (Kirino 2011a: 326). Also, in spite of their contribution to the village as active workers, there is a persistent worry that the women are staying in Japan illegally and could bring trouble to Iwan-mura (Kirino 2011a: 389). Yet it becomes clear during the course of the plot that the Japanese countryside - as exemplified by Iwan-mura - will have to ethnically become more diverse in order to survive. Upon her return to Iwan-mura in 2008, Maya witnesses a flock of young boys calling Suon 'mom', making the impression of looking 'like Suon's children' (Kirino 2011b: 318). Toichi's half-Vietnamese family itself makes the acceptance of otherness, which Kirino seems to be advocating, seem inevitable. Both Suon and her son Akira reveal to Maya that they only want to idle away in Iwan-mura after Toichi's resignation from the chairman's position (Kirino 2011b: 393 ; 395). This could be a hint, pointing towards their difficulties in adjusting to mainstream Japanese society, well-known for its issues of discrimination against Koreans - which is precisely what Kirino might be criticising. For Korean refugees, Iwan-mura becomes a safe and peaceful place - a magazine article in the novel describes the new 'Heisei ${ }^{12}$ Iwan-mura' as a 'place of refuge for weak, oppressed people ... the face of a new utopia' (Kirino 2011b: 9). However, the reality of that claim is kept somewhat ambiguous, since even here the non-Japanese characters are made to feel as outsiders. This 'conflict with otherness' can be read as a critical treatment of the utopian myth of egalitarianism and equality - yet the "elimination of undesirable elements' which Christopher Ferns points out (1999: 90) proves hard in order for the village (and by extension, possibly the Japanese countryside in general) to survive. The point of 'otherness' is, however, also brought about by the chapters detailing Toichi's life in Tōkyō, portrayed quite literally as 'hell' (due to the intense, inescapable heatwave described in these particular sections of the novel) and a dystopian place of perpetual struggle for survival and nonacceptance of outsidersin this case, Toichi, as described above. It can be thus said that Iwan-mura does not serve as a counterpoint to the society the author might aim to criticise-rather, Kirino portrays the problem of intolerance as pertaining to all of Japan, utopias included. Some problems permeate Japanese society (or the Japanese countryside, which Iwan-mura represents) so deeply that there is no escape from them; in that

12 Heisei 平成 is the current (as of 2015) era in Japan, according to the calendar scheme which identifies an era with the reign of the respective emperor. The Heisei era started in 1989, replacing the previous Shōwa 昭和 era (1926-1989). 
respect, Kirino might be suggesting an outright impossibility of a complete, perfect utopia.

\section{Toichi, the (not so) Charismatic Leader}

Another key conflict within Iwan-mura is rooted in Toichi's succession of Soichi as the village's chairman and his problematic leadership, with the deep disagreement of the villagers about Toichi's choices eventually causing the village to split into two fractions. However, it is clear that Soichi-the previous 'charismatic leader' of Iwan-mura - is not exactly a managerial type and probably contributed to Iwanmura's economic downfall himself, yet he is universally loved by the villagers. Soichi admits that he is not fond of physical labor and a life bound to the soil like the one led by his father, Iwan-mura's founder Sohō, and that basically all he cares about is theatre (Kirino 2011a: 63). On another occasion, he explains to Toichi that a (good) leader displays his selfish desires and should be manly and attractive to women - all of which are qualities he apparently is endowed with and which allowed Iwan-mura to 'bloom to a wonderful utopia' (Kirino 2011a: 167). Alice describes Soichi to Toichi as a womanising good-for-nothing man who never did any farming nor housework, and that the village was enjoying loose sexual morals during his prime, saying that 'you became dirty when you were in Iwan-mura. Everybody was running around in the night' (Kirino 2011a: 100-101). Later, she explains the villagers' disdain towards Toichi as a result of the older villagers forgetting their own youth, saying that she and Raga Kazuko went through something similar in the past (Kirino 2011b: 180).

One of the problems about Toichi's leadership is his lack of authority, which is displayed constantly throughout Poritikon. In spite of his hunger for power, he often needs advice, assistance, or just does not have the power to move the other villagers towards a common goal. The 'outsider' farmer Yamaji Hiroshi-who becomes a 'charismatic leader' for the village in his own right (as described below) - proposes that Toichi should become, in a way, a spokesperson for Iwan-mura, a 'charismatic chairman ... a charismatic leader of Japan's agriculture' (Kirino 2011b: 82). Another character with a clear conception of Iwan-mura's future, Tachibana Yūsuke, is introduced late into the novel as an enthusiastic sympathiser (along with his wife Chisa 千紗) to Toichi's cause. However, he soon becomes a threat to Toichi's authority, promoting his ideals of organic farming which would probably be successful with Yamaji and the older villagers as well; but even with someone like Yūsuke ostensibly on his side, Toichi feels left out of the picture of Iwanmura's future (Kirino 2011b: 193-194). The only person who seems to be Toichi's sincere ally, providing him with advice throughout, is Kunita/Kitada; for instance, when he discusses Toichi's lack of agitating ideals as a possible reason for the 
villagers not understanding him and, therefore, not supporting him as the chairman (Kirino 2011b: 106).

It is actually Kunita/Kitada's lung cancer and subsequent death which prompt Maya to visit him in hospital and, consequently, return to Iwan-mura as well, ten years after she had left. His funeral is one of the moments she realises how drastically the village had changed (this change will be described in more detail below). During this time, Kunita/Kitada obviously becomes an integral part of the village, and Toichi's lack of authority becomes evident when he is unable to secure the funeral within the village boundaries as he wishes to. He apologises for this to Kunita/Kitada in his funeral speech, calls him a 'sworn friend', a 'true farmer', and a 'comrade' who could understand Toichi and his ideals, adding that 'Kitada-san lived for Iwan-mura, and he died for Iwan-mura' (Kirino 2011b: 367). Ironically, Toichi harbors a deep mistrust towards Kunita/Kitada at first, even sending him away on his first attempt for membership. However, Kunita/Kitada is portrayed from the start as a wise person, educated in matters of utopia and utopian communities, something which Soichi points out to Toichi during the first visit of Kunita/Kitada's sham family (Kirino 2011a: 66-67).

\section{Figures of Authority and Iwan-mura's Split}

With the character of Kunita/Kitada, the traditional utopian trope of a dialogue wherein a utopian 'insider' convinces the 'traveler' about the superiority of his or her respective utopian society is reversed. Kunita/Kitada is obviously much more knowledgeable in terms of utopia than Toichi is (or, for that matter, possibly any of the village's present members), and advises him in, among other things, matters of leadership or group psychology in numerous passages of the novel. Kirino might be making a slight nod to his education about utopias (over the course of the novel, he gives references to Robert Owen, Tolstoyanism etc.) when Kunita/Kitada claims he used to be a cartographer by occupation (calling to mind Christopher Ferns' assessment that the traveler figure has been replaced by one of a tourist after the 'age of exploration'; Ferns 1999: 19-20), a profession that has since been made obsolete by modern technologies (Kirino 2011a: 43). By the same token, utopias are obsolete in the modern world - Iwan-mura being a prime example — and Kunita/Kitada seems to be aware of this, as he never claims any utopia to be superior to 'traditional' society. Yet the devotion with which he works for the village shows that he believes an alternative society can be made to work properly. Kunita/Kitada can thus be said 
to embody a voice of a 'critical utopia', ${ }^{13}$ understanding utopias as works in progress as opposed to a final solution.

Another character who acts as a counterpoint to Toichi-as a possible leader with charisma and natural authority - is Yamaji Hiroshi, a 54-year old farmer living autonomously on the outskirts of Iwan-mura with his wife, pursuing organic farming and with a reputation of an eccentric (Kirino 2011a: 223-224). Making Yamaji the same age as Kitada/Kunita might be Kirino's way to accentuate his leadership qualities and charisma, which they both share but ultimately exploit in very different ways. The reputation of the Yamajis is that of ascetics, reminiscent of Iwan-mura's first settlers who came along with Takanami Sohō and the Japanese writer Miyazawa Kenji 宮沢賢治. Contributing to this is also their lifestyle centered around rice cultivation, while both abstain from drinking or smoking and wear only the most basic clothing (Kirino 2011a: 372). Yamaji first makes his appearance in the novel during a mutual criticism meeting where the succession of the dining hall management and Soichi's chairman position are being discussed, and immediately earns an applause from the villagers speaking about the village's need to accept young members (Kirino 2011a: 225). In spite of Yamaji's modest demeanour and image, however, it quickly becomes clear that he is not quite honest with the other villagers. Toichi notices that Yamaji enjoys special treatment from the others, using village equipment for his own ends - effectively breaking the village's ruleswithout any repercussions (Kirino 2011a: 383); slowly but surely, Toichi also notices that the Yamajis seem to live much more comfortably than the rest of Iwanmura (Kirino 2011a: 399).

These worries are later confirmed by Maya, who gets on good terms with the Yamaji couple. Toichi realises that these 'ascetics', among other things, sell brand rice, own a cell phone and a computer, and trade online without the rest of the village knowing anything (Kirino 2011b: 28), leading Toichi to think of their house as 'the Dejima of Iwan-mura' (Kirino 2011b: 29). ${ }^{14}$ Yet Yamaji never enters a conflict with any of the original villagers except Toichi, even when the latter makes them aware of the aforementioned disparities - on the contrary, he manages to gain the older villagers' sympathies, effectively splitting Iwan-mura into two factions. Kitada explains to Toichi that Yamaji can gain their trust because he has clear ideals which they can understand, something that he has not been able to achieve, and that

13 Tom Moylan's term 'critical utopia' describes a more progressive strain of utopian writing, which experienced its prime in the 1970 s and which concerns itself with the limitations of traditional utopian texts. In critical utopias, social change is highlighted through the conflict of the originary and utopian societies, and these new utopias have a more dynamic quality to them, in part due to their portrayal as imperfect, developing societies (Moylan 1986: 10-11).

14 Dejima 出島 was a small artificial island located in the bay of Nagasaki, which during the Edo 江戸 period (1600-1868) — and therefore, Japan's period of isolation — served as the sole trading post between Japan and the outside world. Dejima was also the only place where foreign merchants were allowed to live in Japan. 
in spite of idealism being something 'antiquated', it can apparently still move people (Kirino 2011b: 107-108). Yamaji actively contributes to Iwan-mura's split when he starts to call Toichi and his 'allies' spending time together in the village's assembly hall the 'assembly hall group' (shükaishitsu-ha 集会室派). It is important to note that this group consists of almost all of the village's younger members and representatives of the aforementioned 'otherness' (Toichi, Kunita/Kitada, Suon, Hoa, Mei and Akira; possibly Maya), which underlines the notion of a future of the Japanese countryside as more ethnically diverse, as well as Kirino's criticism of ostracising 'otherness' by the older generation (Kirino 2011b: 87). The concept of diversity is only made more obvious on a semantic level by Kirino's decision to base the group in an assembly hall (shükaishitsu 集会室), alluding to their 'coming together'. Kirino ironically proceeds to point out the backwardness of the conservative, older faction of the village when Kunita/Kitada dubs it the 'museum group' (bijutsukan-ha 美術館派) in jest (Kirino 2011b: 91) due to their secret meetings in the village museum, even though free entry to the museum is forbidden according to the village rules (Kirino 2011b: 96). The association of the older, or more conservative generation with the museum also suggests Kirino's critical take on the 'utopian stasis' and the reluctance of this group to allow any substantial change to the village's identity, which might be manifested by the very existence of the museum itself (Brumann 1998: 359). This antagonistic depiction of an older and a younger generation with different goals and ideals might also come across as being somewhat surprising in the context of Kirino's oeuvre, considering her often positive and empowering depictions of seniority, or her strong middle-aged (usually female) protagonists. The only exception to this grouping in Poritikon is Alice, who refuses to side with either faction (Kirino 2011b: 97), although she ultimately contributes to Toichi's denouncement at the end of the novel. Although Toichi is at first unwilling to participate in any sort of fight (Kirino 2011b: 87), he finally succumbs to the splitting and divides the poultry house by painting a black demarcation line inside (Kirino 2011b: 140), letting both factions work for themselves.

\section{The New Utopia: Iwan-mura's Reorganisation and Future Outlook}

In Poritikon's first part, the ultimate fate of Iwan-mura is left open, although it does not end on an altogether hopeless note after the arrival of the organic farmer enthusiast Tachibana Yūsuke and his wife, who propose to contribute to building a new 'Heisei Iwan-mura' (Kirino 2011b: 132). Iwan-mura's subsequent change is witnessed from Maya's perspective in Poritikon's second part, first on television, then through a personal visit, which ultimately leads to Toichi abandoning Iwanmura for good. 
Maya's first sight of the 'new' Iwan-mura is during Toichi's television interview, commenting on the village's success with organic farming and provision of freerange chickens, wearing farming clothing and a white t-shirt with 'Iwan-mura' printed on it to look like ink calligraphy. The shot of Toichi then changes into a scene of rice planting, with two smiling young men unknown to Maya helping Toichi out; ironically, Maya is watching this interview with the yakuza member she ended up with after being sold and with whom she would later have an affair (Kirino 2011b: 253-254). In 2008 she meets the man to whom Maya was sold to, who explains to her that Toichi made Iwan ${ }^{15}$-mura a farming corporation after having success with brand organic vegetables, while also turning the village into an 'agricultural Disneyland' (Kirino 2011b: 263) after experiencing an intense interest in Iwan-mura as a tourist spot, letting children try out farming for themselves (ibid.). In the meantime, Iwan-mura has also become famous for its so-called Iwan Egg Pudding (Iwan no tamago purin イワンの卵プリン), made from local free-range eggs and sold exclusively in the village in matryoshka-shaped bottles-which gain popularity online as collector's items (Kirino 2011b: 266).

Maya's first 'taste' of this new Iwan-mura comes through a poster she sees at a train station on her way there. The poster shows the totem pole, a chicken farm, and two young women holding bamboo baskets full of leaf vegetables, while a blurb on the poster reads 'A utopian village with a flavor of Shirakaba-ha. Hand-grown organic vegetables and free-range eggs. Try out farming yourself!' (Kirino 2011b: 285). She also reads a promotional leaflet distributed by the local tourist information centre - this shows a photograph of old snowshoes and portraits of Raga Makoto and Takanami Sohō (dubbed 'Iwan-mura's ancestors'; ibid.), associating the blurb 'hand-made warmth' (ibid.) with the snowshoes about which Toichi-also portrayed on the leaflet - speaks. He explains that these old, hand-made snowshoes are still being used in Iwan-mura, adding that 'in fact, they have a perfect shape and are very comfortable. Many practical things come from abroad now, but there's nothing that could surpass the warmth and wisdom in hand-made things' (ibid.). In spite of Iwanmura's drastic modernisation, an emphasis on the 'traditional' and 'old' still seems like a viable selling point, catering to the taste for nostalgia or a 'golden age'—such nostalgia being a utopian moment itself.

The first villagers Maya meets after her departure are Suon and Alice, who relay to her their positive experience with Iwan-mura's development. Suon says the villagers now live in prefab apartments, while Hoa lives in a large mansion and the assembly hall is being shown to tourists as a historical building (Kirino 2011b: 289). There are also many people commuting from the neighboring town(s) to work in the

15 Now written in katakana, that is, いわん村 instead of 唯腕村—possibly to reflect its 'modernisation', but also obscuring the meaning of the kanji ('just' or 'only' and 'arm' or 'skill', respectively), making the village's transformation evident. 
pudding factory and, due to the influx of people to the village, a tourist bus stop, public toilets, and a convenience store have been built. Alice claims the village is doing better than before and that she herself is employed in the pudding factory as well (Kirino 2011b: 302).

The possibilities for touristic activities in Iwan-mura are described as well. Visitors usually come by bus, get off at the totem pole, learn about the history of Iwan-mura, and proceed to visit the museum, where they are shown Takanami's paintings and sculptures and Raga's handwritten manifesto. Then they visit the village's old houses to commemorate the founders' achievements and get a 'taste of life' in the Meiji 明治 (1868-1912) and Taishō 大正 (1912-1926) eras. After that, the tourists can visit the vegetable farm and pull out some vegetables from the soil or pluck fruits; during the rice-planting season, it is possible to try planting Yamaji's rice. From the free-range chicken farm, they can buy the famous Iwan-mura eggs and the pudding. They can enjoy meals made from local produce in the farm's organic restaurant, which even produces its own beer. Last but not least, the village has its own souvenir shop selling t-shirts, merchandise with the totem pole design or reproductions of paintings, ceramics, or calligraphy from the village's elderly artists (Kirino 2011b: 327-328). Toichi explains this massive success as the result of luck, with the village taking opportunity of emergent booms such as the slow food movement or popularity of organic produce (Kirino 2011b: 328). The heavy reliance on 'iconography' and symbols also calls to mind the fundamental role of imagery in the construction of a community (Blackshaw 2010: 6).

Yet Maya also witnesses the darker sides of Iwan-mura's success, most strikingly when she visits the Komatsu dining hall after Kunita/Kitada's funeral. She sees a number of women her age with sour expressions on their faces and visibly exhausted, who apparently work at the village's pudding factory or the village farm. At that moment Maya realises that these young people are entirely unaffected by Kunita's death, and that the village itself is in fact something completely different than what the poster promised (Kirino 2011b: 341). Toichi himself is reproached by Alice that the workers at the pudding factory are treated as slaves, and that the village constantly has to look for new workforce because the workers usually flee due to the working conditions, while Yamaji's wife Michiko accuses Toichi of sexually harassing the female staff (Kirino 2011b: 381). Maya also experiences verbal sexual harassment herself during her visit to Iwan-mura while serving drinks, unable to shake off the feeling of 'working in the pub in Sakuragi-chō' (Kirino 2011b: 371) where she is employed, suggesting that even within this utopian society gender disparities are still an issue-if not worse compared to her original stay. It then becomes evident that Kirino subverts the utopian patterns of iyashi 癒し ('healing') present in much of Japanese literature of the past two decades, staying in line with her previous work, most notably Metabora. Neither of the two constructions of (past and present) Iwan-mura comes off as particularly Arcadian- 
starting with its location in a harsh climate (it is telling that Kirino 'moved' the commune from Kōchi on the southern island of Shikoku to the snowy Yamagata, practically opposite of the real Atarashiki mura) to all trials and tribulations the protagonists experience therein. Even if Kazuko's motivation to move back might suggest such a 'healing' potential of living in the 'new' Iwan-mura, Kirino offsets this with the sombre image of exhausted factory workers. Kirino's portrayal of the 'new face of utopia' is even more ambivalent than that of the community that came before it. On the one hand, Iwan-mura manages to overcome economic hardship and find great success, securing a constant living standard for its members or, like in Toichi's case, even luxury. This success, however, comes at a price: The relationships become impersonal or outright strained (as Toichi's unhappy marriage or his subsequent denouncement exemplify), with economic success seemingly being the only acceptable 'ideal' in contemporary Japan. The utopia of old is deadas becomes manifest by Kunita/Kitada's death — and can presently only serve as a product to be consumed. This consumption can take the form of the purchase of a pudding or a short visit, which does not require the tourists to think about the 'mainstream' society they live in from a critical perspective-an impulse under which utopian communities, including Iwan-mura, have been founded. Toichi's mother Kazuko - who ultimately becomes the village's chairwoman in his placemoves back to Iwan-mura, her motivation being that the village provides ample opportunities for work and the healthy environment might help her get cured of her alcoholism. This also points to Iwan-mura's new comfortable living standard as an important factor for living there (Kirino 2011b: 373). On the other hand, utopia does not seem completely 'dead', as the novel's ending suggests: Toichi and Maya leave Iwan-mura together but ultimately decide to build a new community on Hokkaidōin other words, the only choice they seem to have in a world where they are both unable to find a place for themselves is to create a world of their own. Whether that is a good or bad decision remains - in true Kirino fashion-open.

The emphasis on the village's organic farming, healthy environment, and exploitation of, for example, the slow food boom reads positively 'ecotopian' (Kumar 1987: 405-406), as does rooting the novel in the global, contemporary reality and possibly suggesting a way for farming communities to survive. Kirino's setting of an agricultural community in Japan's countryside would be in line with Laurence Davis' proposition of 'grounded utopias' as utopias which might still contribute to some kind of social change by presenting alternative lifestyles (Davis 2011: Locations 3530-3552) - however, Kirino's decision to effectively turn Iwanmura into a thoroughly capitalist corporate entity, complete with a factory, is something that the 'grounded utopias' should be an alternative to. This is much more in line with Ramoneda's (2011) interpretation of a contemporary society as one of financial companies as rulers and citizens as consumers (Locations 3198-3202), contributing to a crisis in utopian thinking and, by extension, the relevance of 
utopias. Coming back to the Tolstoy reference, it seems that farming is not the most honourable profession anymore, and no Japanese 'Ivan' is going to rule the country ever again.

\section{Conclusion}

With Poritikon, Kirino Natsuo proves herself as a writer willing to step outside of her comfort zone and to continuously reinvent her writing and themes, while, at the same time, staying true to her ongoing concern of creating fiction addressing Japan's current social issues. By largely situating her novel in a previously unfamiliar setting, Kirino manages to take up different issues pertaining to Japanese society, while employing many of her recurrent tropes so as not to alienate her established readership. This also allows Kirino to address ongoing concerns of her work, such as persistent gender discrimination or the trials and tribulations of the lower social strata. Kirino remains ambivalent in her creation of a fictional utopia: She introduces Iwan-mura as a commune in a critical state on the brink of dissolution, yet even the 'new face of utopia', as presented in Poritikon's second part, is a far cry from a truly ideal solution.

With Poritikon, Kirino Natsuo employs the genre patterns for which she had been known previously only scarcely. Within the utopian spectrum, it seems fair to call the novel anti-utopian due to Kirino's thoroughly critical treatment of Iwanmura's ideals and utopia itself, while never advocating supremacy of one social system (utopian community and the outside world, respectively) over the other. ${ }^{16}$ Rather, Kirino chooses to emphasise the connection of the two social systems and the impossibility of any utopian system to fully isolate itself from the society which it was born out of. Toichi seems to be the victim of the village's stubborn tendency for such isolation, making him unable to find his place either in the village due to the generation gap or in the outside world (represented by Tōkyō) due to living a completely different life from his peers. Using such a thorough ambivalence, Kirino successfully avoids the pitfalls of prescriptive qualities in utopian writing that are often criticised. Poritikon could also be considered - at least partly-a 'critical utopia', in that it strongly operates with a sense of utopia as a 'work in progress', complete with hardships that this process entails. Iwan-mura might be a society to which the argument of a 'utopian stasis' applies, but is forced to confront change in order to survive - be that accepting foreigners or reinventing itself completely in exchange for economic profit, which in itself is not presented as a 'happy ending'. Considering Kirino's own skepticism towards the potential of literature for causing

16 For a more detailed discussion on the differentiation of the terms 'utopia', 'anti-utopia', and 'dystopia', see Gregus 2014: 26-34, as well as Moylan 2000. 
24 Vienna Journal of East Asian Studies

significant social impact (Yū and Kirino 2009/2012: 146-147), she might as well not be constructing a utopia to change anything after all. 


\section{REFERENCES}

Bandō, Masako 板東眞砂子 and Kirino Natsuo 桐野夏生. “Za shite shi o matazu” 座して死を待 たず [Not to Sit and Wait for Death]. In Hakkaten. Taironshū 発火点: 対論集 [Ignition Point. Interview Collection], edited by Kirino Natsuo 桐野夏生. Tōkyō 東京: Bunshun bunko 文春 文庫, 2009/2012, pp. 215-235

Blackshaw, Tony. Key Concepts in Community Studies. London: SAGE, 2010

Brumann, Christoph. "Ittôen, Atarashiki mura und Yamagishikai: Drei utopische Revitalisierungsbewegungen im Vergleich.” In Soziale Bewegungen in Japan, edited by Claudia Derichs and Anja Osiander. Hamburg: Gesellschaft für Natur- und Völkerkunde Ostasiens, 1998, pp. 345-368

Davis, Laurence. "History, Politics, and Utopia: Toward a Synthesis of Social Theory and Practice.” In Existential Utopia (Kindle Edition), edited by Michael Marder and Patricia Vieira. New York: Continuum, 2011, Locations 3276-3597

Ferns, Christopher S. Narrating Utopia. Ideology, Gender, Form in Utopian Literature. Liverpool: Liverpool University Press, 1999

Frye, Northrop. "Varieties of Literary Utopias." In Daedalus, 94/2, 1965, pp. 323-347

Gregus, Adam. "II Live to Love My Friends, Live to Love the Soil, Live for the People': The (Anti-)Utopia of Kirino Natsuo's Poritikon.” M.A. thesis, University of Vienna, 2014

Kirino, Natsuo 桐野夏生. Kao ni furikakaru ame 顔に降りかかる雨 [Rain Falling on Her Face]. Tōkyō 東京: Kōdansha 講談社, 1993

Kirino, Natsuo 桐野夏生. OUT. Tōkyō 東京: Kōdansha 講談社, 1997

Kirino, Natsuo 桐野夏生. Yawaraka na hoho 柔らかな煩 [Soft Cheeks]. Tōkyō 東京: Kōdansha 講談社, 1999

Kirino, Natsuo 桐野夏生. Tamamoe! 魂萌え! [Awaken Your Spirit!]. Tōkyō 東京: Asahi shinbun-sha 毎日新聞社, 2005

Kirino, Natsuo 桐野夏生. Metabora メタボラ [Metabola]. Tōkyō 東京: Asahi shinbun-sha 毎日新 聞社, 2007

Kirino, Natsuo 桐野夏生. Tōkyō-jima 東京島 [Tōkyō Island]. Tōkyō 東京: Shinchōsha 新潮社, 2008

Kirino, Natsuo 桐野夏生. Yasashii otona 優しいおとな [Gentle Adults]. Tōkyō 東京: Chuō kōronsha 中央公論新社, 2010

Kirino, Natsuo 桐野夏生. Poritikon (jō) ポリティコン (上) [Politikon, Volume 1]. Tōkyō 東京: Bungeishunjū 文藝春秋, 2011a

Kirino, Natsuo 桐野夏生. Poritikon (ge) ポリティコン (下) [Politikon, Volume 2]. Tōkyō 東京: Bungeishunjū 文藝春秋, 2011b

Kumar, Krishan. Utopia and Anti-Utopia in Modern Times. Oxford: Blackwell, 1987

Minagawa, Hiroko 皆川博子 and Kirino Natsuo 桐野夏生. “Akui o shōsetsu de shōka sasetai” 悪 意を小説で昇華させたい [With Novels, I Want to Sublimate Malice]. In Hakkaten. Taironshū 発火点: 対論集 [Ignition Point. Interview Collection], edited by Kirino Natsuo 桐野夏生. Tōkyō 東京: Bunshun bunko 文春文庫, 2009/2012, pp. 33-57

Mishima, Yukio 三島由紀夫. Utsukushii hoshi 美しい星 [Beautiful Star]. Tōkyō 東京: Shinchōsha 新潮社, 1962

Moichi, Yoriko. "Japanese Utopian Literature From the 1870s to the Present and the Influence of Western Utopianism.” In Utopian Studies, 10/2, 1999, pp. 89-97

Moylan, Tom. Demand the Impossible: Science Fiction and the Utopian Imagination. London: Methuen, 1986 
Moylan, Tom. Scraps of the Untainted Sk:. Science Fiction, Utopia, Dystopia. Boulder: Westview Press, 2000

Ōe, Kenzaburō 大江健三郎. Chiryōtō 治療塔 [Tower of Treatment]. Tōkyō 東京: Iwanami shoten 岩波書店, 1990

Rapp, Christof. Aristoteles zur Einführung. Hamburg: Junius-Verlag, 2001

Sasaki, Atsushi 佐々木敦 and Kirino Natsuo 桐野夏生. “'Risōkyō' ka 'zetsubōkyō' ka. Ima kono kuni de okiteiru koto”「理想郷」か「絶望郷」か。いまこの国で起きていること [Utopia or Dystopia? What's Happening in This Country Now]. 2011, http://bunshun.jp/pickup/politikon/, accessed December 2014

Satō, Masaru 佐藤優 and Kirino Natsuo 桐野夏生. “'Mienai hinkon’ ga kono kuni o mushibamu” 「見えない貧困」がこの国を蝕む [An 'Invisible Poverty’ is Ruining This Country]. In Hakkaten. Taironsh $\bar{u}$ 発火点: 対論集 [Ignition Point. Interview Collection], edited by Kirino Natsuo 桐野夏生. Tōkyō 東京: Bunshun bunko 文春文庫, 2009/2012, pp. 191-214

Tolstoy, Leo. "Ivan the Fool.” In The Harvard Classics Shelf of Fiction, XVII, Part 2, edited by Charles W. Eliot and translated by Count Narraikow. New York: P.F. Collier \& Son, 1917; Bartleby.com, 2000, http://www.bartleby.com/317/2/, accessed May 2015

Tunçel, Ahu. "The Ontology of Zoon Politikon.” In Synthetis philosophica, 27/2, 2012, pp. 245255

Yū, Miri 柳美里 and Kirino Natsuo 桐野夏生. “Zankoku na sōzōryoku no hate” 残酷な想像力の 果て [The Ends of Cruel Imagination]. In Hakkaten. Taironsh $\bar{u}$ 発火点: 対論集 [Ignition Point. Interview Collection], edited by Kirino Natsuo 桐野夏生. Tōkyō 東京: Bunshun bunko 文春文庫, 2009/2012, pp. 129-154 
あいばん

Aiban

Auto

Atarashiki mura

Bandō Masako

bijutsukan-ha

Edo [period]

Dejima

gunzō shōsetsu

Heisei

iyashi
アオト

新しき村

板東眞砂子

美術館派

江戸

出島

群像小説

平成

癒し
The theatre troup of the Iwan-mura commune, led by Takanami Soichi. The name Aiban seems to be a pun on the name Ivan (from Leo Tolstoy's Ivan the Fool, after which the commune itself is named)

Kirino Natsuo's breakthrough novel, in which she describes a descent of four desperate, middle-aged housewives into crime after the youngest one of them kills her husband in a fit of rage

Commune founded in 1918 by writer

Mushanokōji Saneatsu 宮沢賢治 originally in the Miyazaki Prefecture, now located in Saitama. The fictional Iwan-mura is partly based on Atarashiki mura

Japanese writer (1958-2014), known for her horror novels

After the commune's split following conflicts over its leadership and direction, its predominantly older members form this informal group ("museum group"). By making the village's museum their "headquarter", Kirino seems to comment on their aim to preserve conservative world view and values, a "utopian stasis" and an unwillingness to change

Period in Japanese history (1603-1868), marked by Japan's political isolation and the dominance of the Tokugawa shogunate. It came to a close with the Meiji restoration in 1868, after which Japan underwent a rather swift process of 'Westernisation'

An artificial island located in the Nagasaki bay, which served as the single point of trade between Japan and outside countries during the isolationist Edo period. It was here that foreign traders (notably those from the Netherlands) were stationed

'Ensemble novel', a novel featuring a large cast of characters (possibly without a prominent protagonist)

The current era in Japanese history, which started in 1989

A prominent trope of 'healing', present in Japanese literature especially in the 1990s. Iyashi novels describe a positive transformation of their protagonists, notable examples are works of Yoshimoto Banana よしもとバナナ. 
Iwan-mura

Iwan no tamago purin

joryū bungaku

Kao ni furikakaru ame

Meiji

Metabora

Minagawa Hiroko

Mishima Yukio

miso

Miyazawa Kenji

mizu shōbai

Mushanokōji Saneatsu

Ōe Kenzaburō

Poritikon
いわん村 or 唯腕村

イワンの卵プ

リン

女流文学

顔に降りかか る雨

明治

メタボラ

皆川博子

三島由紀夫

味噌

宮沢賢治

水商売

武者小路実篤

大江健三郎

ポリティコン
A fictional commune located in the northern prefecture of Tōhoku and the stage for most of Poritikon's plot

Iwan-mura's flagship product after its radical reinvention during the novel's latter part; an egg pudding housed in a matryoshka-shaped bottle, which is described as a significant factor in its popularity

'Women's literature', does not describe any specific genre, but works written by women Kirino Natsuo's mystery debut, also officially credited as her debut novel. She followed it up with two more novels and a short story collection starring the female detective Murano Miro.

Era in Japanese history (1868-1912). Marked by the radical modernisation and 'Westernisation' of Japan

Kirino Natsuo's novel, originally serialised in the Japanese daily newspaper Asahi shinbun 朝日新 聞. It follows its amnesiac protagonist, who lost his memory after traveling to Okinawa to take part in a group suicide

Japanese writer (b. 1930), known for her mystery, fantasy, horror, and historical fiction

One of the most prominent Japanese literary figures of the 20th century, novelist, poet, playwright, and film director (1925-1970) Japanese seasoning sold as a thick paste, consisting primarily of fermented soy beans. It is the basis of the miso soup, a staple of Japanese cuisine

Poet and author of children's literature (18961933)

'Water trade', an euphemism for jobs in the sex industry; the term is usually associated with female sex workers (e.g. so-called 'hostesses', prostitutes etc.)

Novelist, playwright, poet, and philosopher associated with the Shirakaba-ha movement (1885-1976)

One of the most important Japanese novelists in the 20th century (b. 1935), Nobel Prize laureate (1994)

Novel by Kirino Natsuo, originally serialised in the Shükan bunshun (August 2007-November 2008) and the Bessatsu Bungeishunjū (January 2009-November 2010), focusing primarily on the lives of its two protagonists - Takanami Toichi, a 


$\begin{array}{ll}\text { rijichō } & \text { 理事長 } \\ \text { Sasaki Atsushi } & \text { 佐々木敦 } \\ \text { Satō Masaru } & \text { 佐藤優 } \\ \text { shakai-ha } & \text { 社会派 }\end{array}$

shiitake

Shirakaba-ha

Shōwa

shūkaishitsu-ha

sōgō hihan-kai
椎茸

白樺派

昭和

集会室派

総合批判会 native of the Iwan-mura commune, and Nakajima Maya, a rootless outsider who arrives to Iwanmura on the run after her mother's arrest. With the setting of the utopian commune, Kirino explores diverse themes such as the meaning of nationality in Japan, the economic problems of rural Japan, or the possibility of creating a society of one's own design, among others

'Chairman', in the novel Poritikon used to describe the 'leader' of the commune Literary critic and professor of literature criticism at the Waseda University (b. 1964)

Japanese writer (b. 1960), formerly active at Japan's Ministry of Foreign Affairs

Term used to describe mystery novels with a focus on social criticism, i.e. not classical 'whodunits', but rather novels exposing societal ills as causes for crime

Mushrooms growing in Japan (although also found in other regions, such as Southeast Asia, and cultivated worldwide) with a diverse culinary use, both fresh and dried

Literary group associated with the magazine Shirakaba 白樺, part of the anti-naturalist movement, active in the early 20th century. Credited with familiarising the Japanese public with European impressionist and postimpressionist art

Era in Japanese history (1926-1989); this period saw Japan's shift into more radical right-wing politics, its military rise prior to World War II, Japan's defeat as well as its economic 'miracle' following the postwar crisis, which culminated in the prosperous 1980s with their 'bubble economy' Similar to the bijutsukan-ha (see above), the shükaishitsu-ha ("assembly hall group") is an informal circle of Iwan-mura's inhabitants who side with the protagonist Toichi during power struggles which overtake the village. By situating their 'headquarter' in an assembly hall, Kirino might be underlining their positions as outsiders within the commune 'Mutual criticism meeting', describes a practice of regular open discussions on Iwan-mura's management and other matters. Also practiced in real communes around the world 
taiga shōsetsu

Taishō

Tamamoe!

Tōkyō-jima

toshi shōsetsu

tankōbon

umeboshi

yakuza

Yasashii otona

Yawaraka na hoho
大河小説

大正

魂萌え！

東京島

都市小説

単行本

梅干

ヤクザ

優しいおとな

柔らかな煩
Roman-fleuve; a long-form novel focusing on a life of an individual, of a family, or a group of people

Era in Japanese history (1912-1926), significant politically for the so-called 'Taishō democracy' Novel by Kirino Natsuo, originally serialised in the daily newspaper Asahi shinbun in 2004. It deals with the journey of its protagonist Toshiko to rediscover herself at the brink of sixty after her husband's death and her subsequent rediscovery of his years-long illicit affair

Novel by Kirino Natsuo, originally serialised from 2004 to 2007 in the magazine Shinchō and also adapted into a film in 2010. Told from multiple perspectives and inspired by the real "Anatahan queen incident", the novel deals with interpersonal politics of a group of over twenty men and a single woman stranded on a deserted island

Kirino Natsuo's description of her body of work prior to Poritikon, with which she tried to branch out of her usual mode of writing - she usually deals with novels in urban settings and focuses on issues related to lives in cities. In her opinion, even her novel Tōkyō-jima fits into this category despite taking place on a deserted island Japanese term for a hardcover edition, usually also the first release of a novel in book form (often preceded by serialisation in a literary magazine, newspaper etc.)

Pickled ume 梅 fruits, also referred to as pickled plums. Often used in rice balls

Term for Japan's notoriously famous organised crime syndicates

Novel by Kirino Natsuo, originally serialised in the daily newspaper Yomiuri shinbun 読売新聞 (February-December 2009). Taking place in a near future in abandoned Tōkyō following Japan's total economic collapse, it follows its teenage, homeless protagonist Ion as he tries to discover his identity and origins while struggling to survive in the dangerous streets and underground of the metropolis

Novel by Kirino Natsuo, originally published in 1999 and awarded the coveted Naoki Prize 直木 賞. Originally conceived as an entry in her mystery series featuring the detective Murano Miro, it was rewritten as the story of Kasumi, 
Yoshimoto Banana

よしもとバナ

ナ whose daughter Yuka mysteriously disappears during a family trip to Hokkaidō, which served as a pretext for Kasumi seeing her lover, a family friend. The novel follows Kasumi's attempts to find out what happened to Yuka, together with a police detective dying of cancer, and her coming to terms with the fact she might never know the truth

Japanese novelist (b. 1964) who became famous with her debut novel Kicchin キッチン (Kitchen), subsequently published in translation all over the world. Often regarded as primarily targeting a young audience, Yoshimoto's works are famous for their accessible style and optimistic messages. Her texts are often categorised as iyashike $i$ 癒 系, or 'healing literature' 